\title{
The Caucasus 3 Plus the Baltic 3 and Economic Cooperation with China $^{1}$
}

\author{
Vakhtang Charaia \\ Faculty of Economics and Business, \\ Tbilisi State University \\ Chavchavadze ave 1 , \\ Tbilisi 0178, Georgia \\ E-mail: vakhtang.charaia@tsu.ge \\ Archil Chochia \\ Department of Law, \\ Tallinn University of Technology \\ Akadeemia tee 3 , \\ Tallinn 12618, Estonia \\ E-mail: archil.chochia@taltech.ee \\ Mariam Lashkhi \\ Faculty of Economics and Business, \\ Tbilisi State University \\ Chavchavadze ave 1 , \\ Tbilisi 0178, Georgia \\ E-mail: mariam.lashkhi09@gmail.com
}

Abstract: This study analyses China's One Belt, One Road (OBOR) initiative for the Baltic and South Caucasus countries. Trade, Foreign Direct Investments and transit potential are taken as main factors for the cooperation. A clash of China and the West in pursuing economic leadership is taken into account. The study suggests a new, alternative route for the OBOR initiative through the Caucasus, which has all the needed infrastructure and readiness for being started. Moreover, Georgia is not new to the EU preferences, it has experience of GSP+ and now the unique achievement of free trade regimes with the $E U$

\footnotetext{
This work was supported by Shota Rustaveli National Science Foundation of Georgia (SRNSFG) [YS-2016-66207, The Impact of MNE Motivation on Georgian Economy].
} 
and China is also taken as an alternative route and an advantage for the Caucasus and the Baltic States.

Keywords: $16+1$ cooperation, Baltic States, BRI, Caucasus, FDI, international trade, $O B O R$

\section{Introduction}

Trade wars, ambiguous politics, socioeconomic instability, tensions between partner countries and so forth have become a regularity in the era of globalization. It is rather predictable that for the next decades, the problems will not be solved easily, but hit the world with new strength. The scale of cooperation between the world's leading economies is under threat. Small states are facing an even higher risk for their sustainable economic development because of the geopolitical games and trade confrontation of bigger states (Dobrin \& Chochia, 2016).

After experiencing the negative effects of the 2008 financial crisis, each country recognized the importance of export as a generator of recovery (Elteto \& Antalóczy, 2017, p. 56). Therefore, until now the European Union seemed to be interested in closer economic cooperation with China, but it turns out that Western-European countries are not limiting their efforts to slowing down the steady growth of Chinese economic drive, explaining it with China's needs to trade fairly, respect intellectual property rights and meet its World Trade Organisation (WTO) obligations (Šteinbuka et al., 2017, p. 99). According to the data, in 2016, China was the largest exporter of goods in the world $(17 \%$ of the total world exports) and the third largest importer (12\% of the total world imports). Manufactured goods accounted for $85 \%$ of the total EU exports to China, which is great, but the amount of manufactured goods export from China to EU is even more impressive-97\% (Eurostat, 2017).

China's global aspirations are growing, but so far limited. After decades of transformation and rapid Gross Domestic Product (GDP) growth on the local level, the Chinese state and private enterprises are enhancing Foreign Direct Investment (FDI) like never before, and one of the key instruments to achieve this goal, the Belt and Road Initiative (BRI), also known in academic and political discourse as 'One Belt, One Road' (OBOR) is considered (Kerikmäe $\&$ Zuokui, 2017). The aim of the initiative, widely perceived as China's strategic 'soft' behavior, is to gradually boost the country's power in the world (Kaplan, 2017, p. 11). 
Despite the fact that neither the Baltic States nor the South Caucasus countries are directly linked to the project or even mentioned on the main roads from China to the rest of the world according to the OBOR map (Papava \& Charaia, 2017a; Charaia, 2017b), the authors believe there could be alternatives and the European gate should be started in the Caucasus. The potential of the Baltic States and the South Caucasus is underestimated; however, this problem can be fixed.

\section{China and EU trade and FDI}

The first important document on Trade and Cooperation Agreement between the EU and China was signed in 1985 (Muenchow-Pohl, 2012), since then China has become the second largest trade partner to the EU, whereas the EU has become China's number one trading partner, overwhelming the point of 500 billion US dollars in annual bilateral trade. However, the continuing negative trade balance (175 billion euros in 2016) is exerting its own impact on the overall cooperation. In 2016, only three countries in the EU-Ireland (256 million euros), Finland (761 million euros) and Germany ( 7 billion euros) - had positive trade balance with China, while all the other countries are on the negative trend-Netherlands ( -54 billion), UK (-37 billion), Italy (-16 billion), Spain (-15 billion), France (-10 billion), Lithuania ( -585 million), Estonia (-473 million), and Latvia (-280 million euros), reaching the total negative trade balance of 175 billion euros (Eurostat, 2017).

However, despite the negative trade balance some European countries, like Belgium, Netherland, Denmark, the Slovak Republic, Hungary and some others, are highly dependent on trade with China, exporting machinery, chemicals, nuclear reactors, electric equipment and many other products, equal up to $2 \%$ of their national GDPs (MERICS, 2015). Therefore, limiting import from China, which could create a mirror effect from the opposite side, can harm European countries as well.

The goods traded among the EU and China are diversified, but the top 20 traded goods covered around $44 \%$ of the total trade in 2016, with telecommunications equipment being traded the most, followed by automatic data processing machines and motor cars and vehicles (Eurostat, 2017). To minimize the trade deficit and stop massive invasion of Chinese products, the EU has graduated many products out of the GSP scheme. However, the strength in steel, aluminum and cement production, in addition to dumping and subsidy policies (Barone, 
2015; Yalcin et al., 2016) makes Chinese products highly competitive worldwide and its trade balance positive. An open trade war with China, at a scale offered by the United States, does not seem to be acceptable for the EU authorities, but tension is still rising.

Another important aspect is related to the FDIs. Unlike the positive attitude from a few years ago, especially in the period of the 2008 financial crisis (OkanoHeijmans \& van der Putten, 2011, p. 8), the EU now proposes a new treatment of investments - screening of FDI. The list of screening factors are proposed but not limited to: (a) Critical infrastructure; (b) Critical technologies; (c) Security of supply and critical inputs; (d) Access to or possible control over sensitive information; (e) Whether the foreign investor is controlled by the government of a third country, including through significant funding (Yin \& Zhang, 2017). While the readiness and openness for FDI is expected to stay in place, the EU is also taking care about the security and public order in the Union.

Making sure that commanding a one-size-fits-all mechanism will not be supported by all Member States, the European Commission found a middle ground in information sharing. Despite the fact that the Western-European countries are willing to act more strictly to FDIs, especially to Chinese ones, they seem to lack support in Eastern Europe, especially in terms of Chinese investments. Since each country will be in charge of approving or declining particular foreign investment, it is widely expected to raise tensions within the EU. Also, it will become more and more problematic for the EU to maintain its honest stand to the principles of open market, while feeling the need for smarter action. Furthermore, it is important to underline that unlike in previous years, when the dominant Chinese investors were presented as state-owned companies, in 2014 it happened for the first time that privately owned Chinese companies overtook in the total amount of investments to the EU, so the EU is concerned.

It is important to underline that the EU is not alone in trying to protect their economy. According to the UNCTAD 2017 report, approximately one-fifth of all newly adopted investment policy measures in 2016 restricted or regulated foreign investment: Canada issued Guidelines on the National Security Review of Investments; Indonesia imposed a $20 \%$ limit on foreign ownership in companies that offer electronic payment services; Namibia adopted a new investment law, reserving certain business activities, including retail; Brazil reversed a liberalization measure of 2016 related to domestic airlines, and so on.

It will not be easy to stop Chinese investments in the EU (controlled by government or aiming to receive a comparative advantage from investment). In less than 
a decade, Chinese investments in the EU have increased almost twenty-fold, reaching 35 billion euros in 2016. Moreover, in 2016 alone, China's FDI to the EU has increased by $77 \%$ compared to the previous year, with the specific focus on the leading EU economies - Germany, France and the UK, with 11 billion euros to Germany accounting for $31 \%$ of total Chinese investment in Europe for the year 2016. The figures for the years 2000-2016 show that the UK and Germany, with Italy and France, are those receiving the biggest amount of FDI, while the results of the Eastern European countries look less impressive (Fig. 1).

Figure 1. Chinese FDI in the EU-28, in 2000-2016, million euros

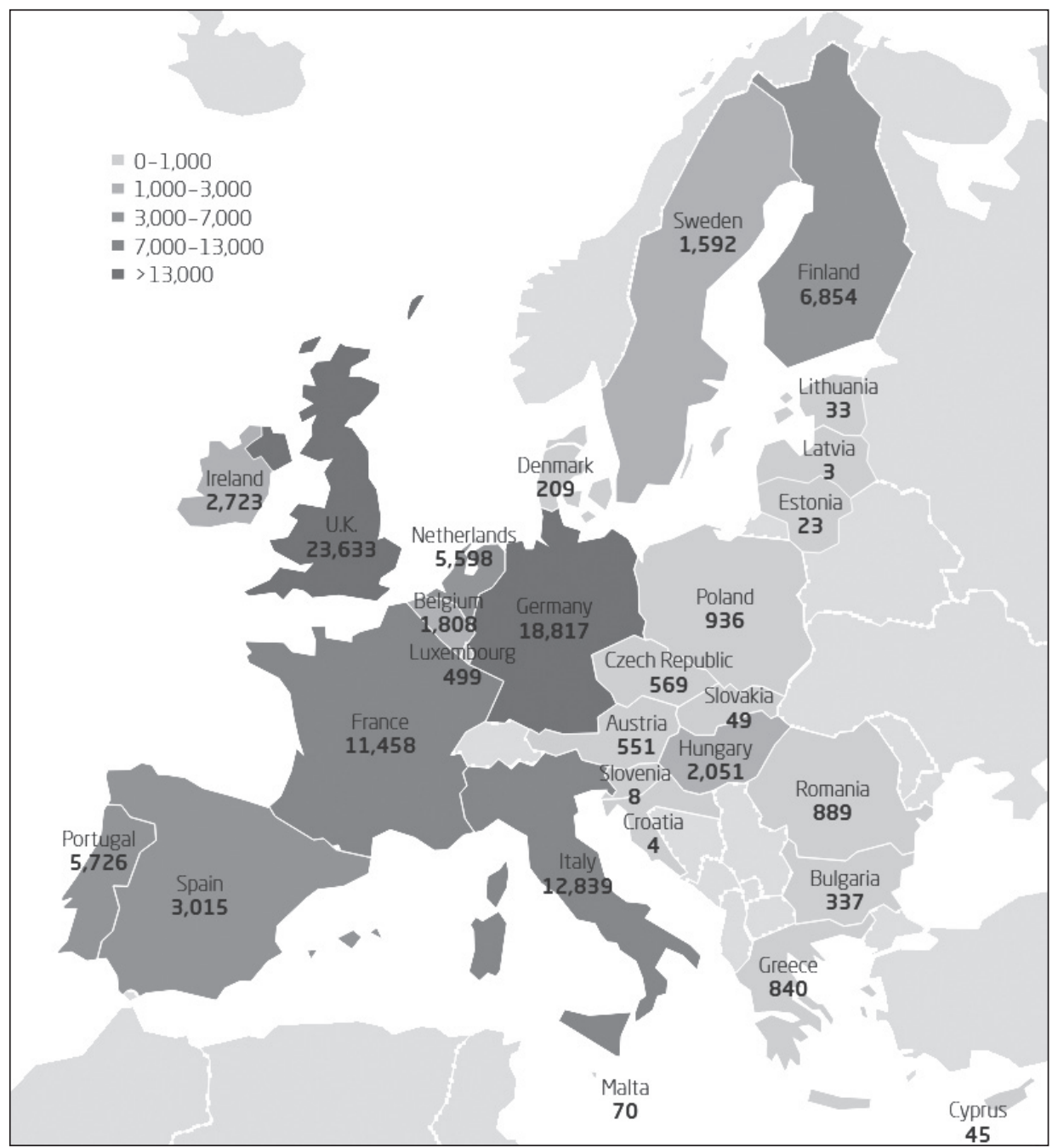

Source: Hanemann \& Huotari, 2017 
On the other hand, attracted by cheap labor force, cost-efficient production and proximity of a growing market, the EU has invested large amounts to China, having the biggest FDI stock in China (Hansakul \& Levinger, 2014, p. 11; Hellström, 2016, p. 32), equal to around 170 billion euros, with the leading positions of Germany (38.5 billion euros), France (16.5 billion euros), Italy (10.6 billion euros), the UK ( 8.7 billion euro) and the Netherlands (6.7 billion euros) (Hansakul \& Levinger, 2014, p. 11). However, in the meantime, according to the statistics, the amount of EU investments in China continued to decrease for the fourth year in a row, finishing with 8 billion euros in 2016 (25\% less than in 2015), because of regulatory obstacles, including cyber regulation (Rasmussen Global, 2017) - a headache for foreign companies. New regulations are totally different from the one offered by China's "open-door" policy announced by Deng Xiaoping in December 1978, after which German and Scandinavian companies managed to build a strong presence in China in the 1980s and the 1990s (Larcon, 2017).

China's FDI stock in the EU-28 is equal to 34.9 billion euros, which is less than $1 \%$ of the total inward FDI stocks in the EU. This is, to a certain extent, a very low number compared to the Chinese FDIs to the USA, equal to almost 2.4 trillion US dollars or $2 / 5$ of the total inward FDI stocks in the EU. Based on the numbers it is not clear why Chinese investments to the EU receive such significant media coverage, but it is also true that Chinese investments to the EU have boomed since 2013, especially in the light of decreasing the EU investments in China for the same period of time (see Fig. 2). It is also important to underline that the area of Chinese FDI deployment area in the EU is very limited. In 2015, only five states, namely Italy, France, the UK, the Netherlands and Germany accounted for 3/4 of all Chinese FDIs in Europe (Hellström, 2016, p. 16).

Figure 2. The amount of Chinese and EU FDI

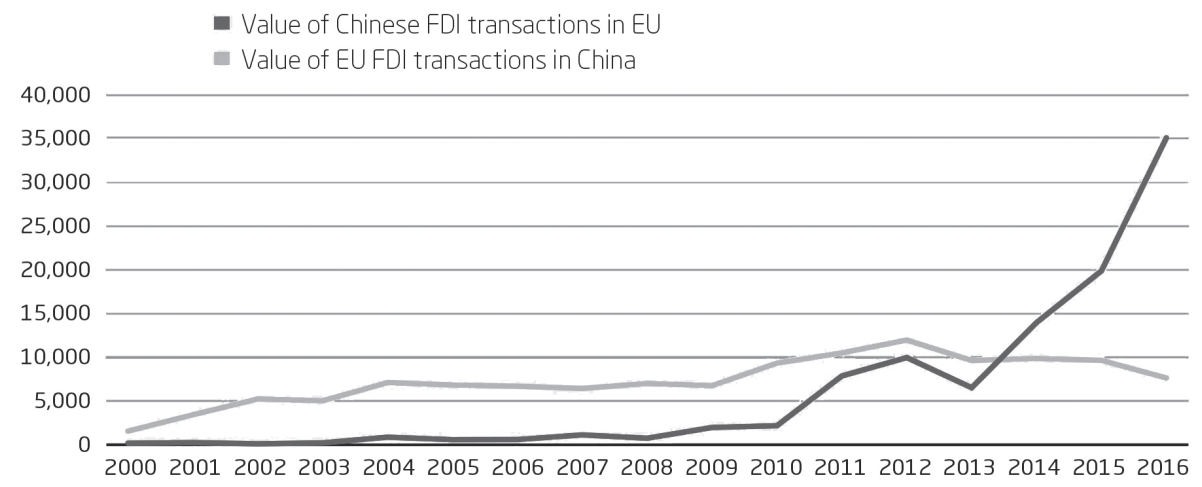

Source: Hanemann \& Huotari, 2017 
High media coverage could probably be explained by some of the biggest Chinese investments made into European companies, which has a psychological impact on the EU authorities in particular: ChemChina's 7 billion euro acquisition of the Italian tyre producer Pirelli; 6.7 billion euro investment in the Finnish gaming company Supercell by a Tencent-led consortium; Midea's acquisition of the German robotics company KUKA for 4.4 billion euros; a $49 \%$ stake by a Chinese consortium in the UK data center operator Global Switch for 2.8 billion euros; HNA's acquisition of the aircraft leasing firm Avolon for 2.3 billion euros; Ctrip's 1.6 billion euro acquisition of the British travel platform Skyscanner, and so on (Hanemann, 2017, pp. 24-25). As a result of the massive "investment attack", Chinese companies are mainly aiming to the following industries: Information and Communications Technology (ICT), automotive and real estate, as well as utilities, transport and infrastructure (Fig. 3).

Figure 3. Chinese FDIs in different fields of EU's economy

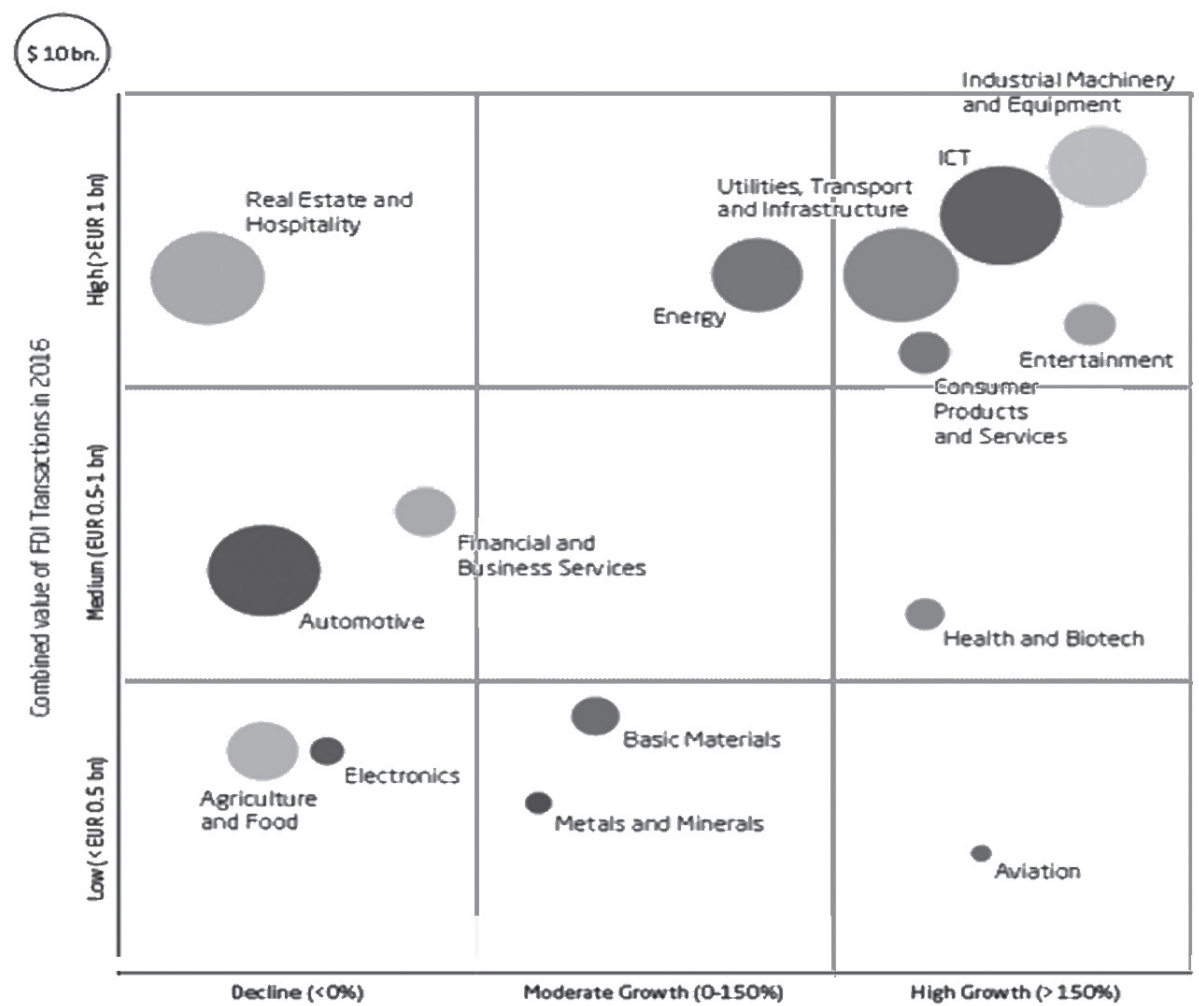

Source: Hanemann \& Huotari, 2017 
Aiming to the global economic leadership, China has proposed to the world a BRI initiative, which implies China's global strength, however limited so far. It is obvious that China is not (yet) as strong and independent as Beijing would have desired. The dominance of the US dollar in global trade, the military strength of NATO, geo-political and economic tensions with the Western countries limit China's ambitions, but the question is - for how long? China is already trying to play the role of an Asian leader by establishing an Asian Infrastructure Investment Bank, by offering free trade regimes to many countries in different regions and continents, by trying economic expansion method and by deploying its soft power in action worldwide.

\section{An alternative route for $\mathrm{OBOR}$}

Unfortunately for the Baltic States and the South Caucasus states, they are not presented on the official OBOR map. The land route from China to Europe proposed by Beijing goes around the Caucasus, through Iran and Turkey. The authors argue that this is an unreliable route for stable transportation, moreover a route through Azerbaijan and Georgia would have great potential and infrastructure. Even choosing the Iran route, there is a possibility of connecting Tehran with Yerevan and further on with Anaklia Port in Georgia; however this route, unlike the former, Aktau-Baku-Anaklia, has to attract investments in the amount of up to 3 billion US dollars, which could postpone its implementation despite the optimistic considerations of the Armenian government. As it is clearly seen in Figure 4, Azerbaijan and Georgia with the already existing welldeveloped railway connections (Papava \& Charaia, 2014) could play a great role in providing an alternative OBOR route, reaching farther to the Baltic States and the Baltic Sea region. Both trade and investments could be promoted through this corridor. Moreover, cargo sent from Lianyungang, China's easternmost port city, would take a maximum of 14-15 days to reach Istanbul, which is quite incredible, given that the same journey by sea takes about 45 days (Shelia, 2015).

Considering the free trade regimes that Georgia has with the EU and China, the alternative OBOR route has real potential, not only as a transit corridor but also to attract later on Chinese and EU investments to export to the European and/or Chinese markets. Since China and the EU are in some sort of economic confrontation (while being great partners as well), Georgia should be considered as a great ground for the EU companies to produce and export to China with 
no tariff barriers (Lashkhi, 2017). On the other hand, Chinese companies and products facing different kind of limitations and negatively affected by graduation from the EU's Generalised Scheme of Preferences (GSP) list, and thus not able to export different goods under the preferences, could perfectly use the territory of Georgia to increase their further trade through the country.

Figure 4. Initial and alternative corridors for the OBOR initiative

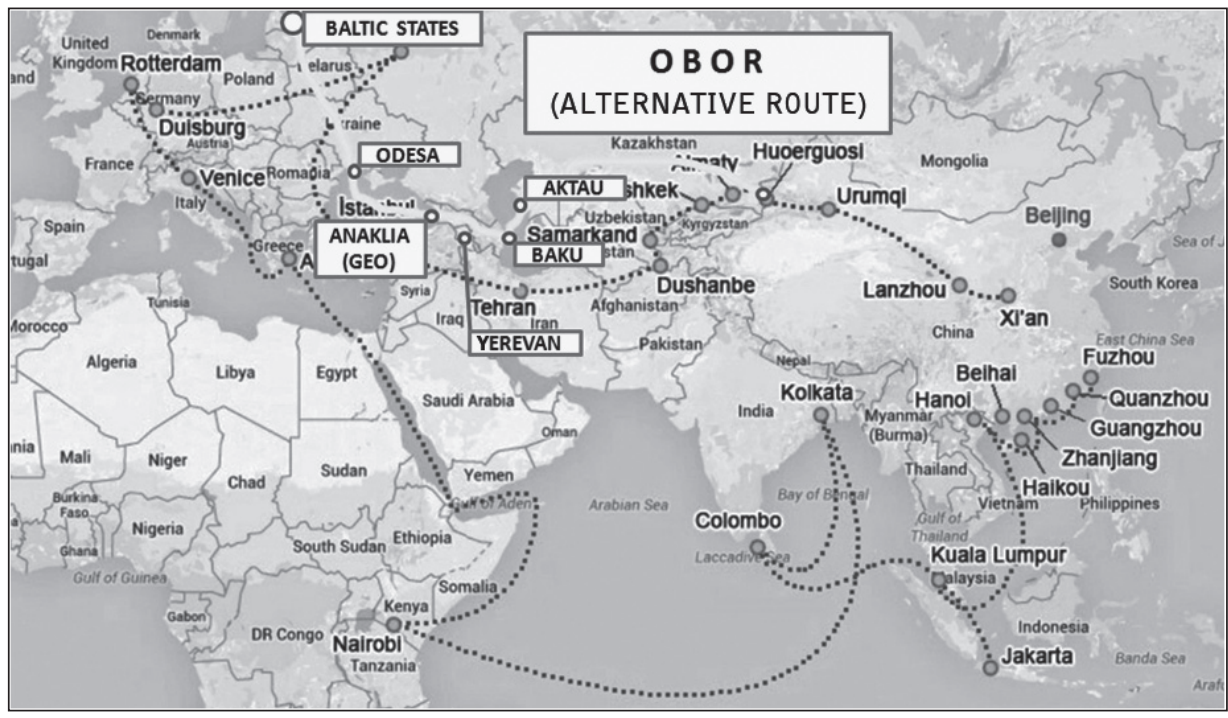

\section{The Caucasus plus the Baltics, opportunities with China}

The current investment boom from Chinese companies have raised concerns among the European public, media and policymakers about the future of national security (Okano-Heijmans \& van der Putten, 2011, p. 10). It is understandable, since especially ports, railways, electricity grids, power plants, media, knowhow and many other so-called strategic assets, are attracting real interest among Chinese companies. However, it should be remembered that FDIs are not only a threat, but a source of financial income that stabilizes the economy, creates new workplaces and maintains the existing ones, increases income for state budgets, and so forth. Therefore, no one should blame particular countries in their pursuit for better life standards, which mainly come through economic progress. Unfortunately, not everyone will be able to get these benefits, but many still will. 
Starting in 2012, China's 16+1 cooperation platform, including the Baltic States, eight other Eastern European countries and five Balkan states on-board, the initiative aims at fostering economic cooperation between the regions (Zhang et al., 2017, p. 85). However, it ended up being seen as a PR initiative aimed at dividing the EU (Rassmussen Global, 2017). Chinese FDIs in Eastern Europe, despite the OBOR-associated investment promises by Beijing under the $16+1$ platform, ended with the PR campaign only (Hanemann \& Huotari, 2017, p. 6). On the other hand, Baltic States in particular are satisfied with the results and are waiting for further boost in cooperation, without antagonizing Brussels, increasing their visibility in China and enhancing people-to-people linkages (Bērziņa-Čerenkova, 2018).

Despite minor political problems with Lithuania and Estonia (related to the Dalai Lama's visit) a few years back, economic cooperation is on the rise in all three Baltic States. Even though the amount of FDI is so far not reaching very high, numerous treaties and agreements signed between China and the Baltic States are expected to bring those investments (Ferraro et al., 2017). Imagining the potential of such cooperation, we should remember the potential of the Belt and Road project with almost limitless capital support, including 40 billion US dollars from the Silk Road Fund, 100 billion US dollars from the Asian Infrastructure Investment Bank and an extra 50 billion US dollars from the New Development Bank. In addition, the CITIC Group is ready to invest up to 113 billion US dollars. (Bochra, 2015, pp. 60-62)

The Baltic States saluted a new avenue for collaboration with China, aiming at declining trade deficit which amounted to more than 2 billion US dollars in 2016, attracting new FDIs (for the year 2016: Estonia-29 million, Lithuania-33 million and Latvia - 1 million US dollars), proposing the local infrastructure as a hub for China-EU trade, the problem turned out to be the limited awareness about the strong sides of Estonia, Latvia and Lithuania in China, called the lack of name recognition. However, in the 21st century the lack of information is easy to overcome and the Baltic States started frequent visits to China, as well as inviting Chinese to return visits. According to the Estonian Ministry of Foreign Affairs, Estonian visa applications in China have increased 55\% in 2016 and 2017, while the country has opened 15 centres in China for submitting visa applications.

Unlike the other Eastern European states frustrated with the level of FDI and trade with China since 2012, the Baltic States are not overestimating their chances and are moving in a right direction, making haste slowly but promisingly. Therefore, Latvia has increased its exports to China since 2012 from 47 to 117 million 
euros; Lithuania from 67 to 123 million euros, while Estonia has increased it from 101 to 168 million euros. The Baltic States were also successful with Chinese visitors, their number growing in 2016 by $57.8 \%$ in Latvia, $25.3 \%$ in Lithuania, and 24.2\% in Estonia (Bērzina-Čerenkova, 2018).

Figure 5. Map of cooperation between China, the Baltic and the South Caucasus states

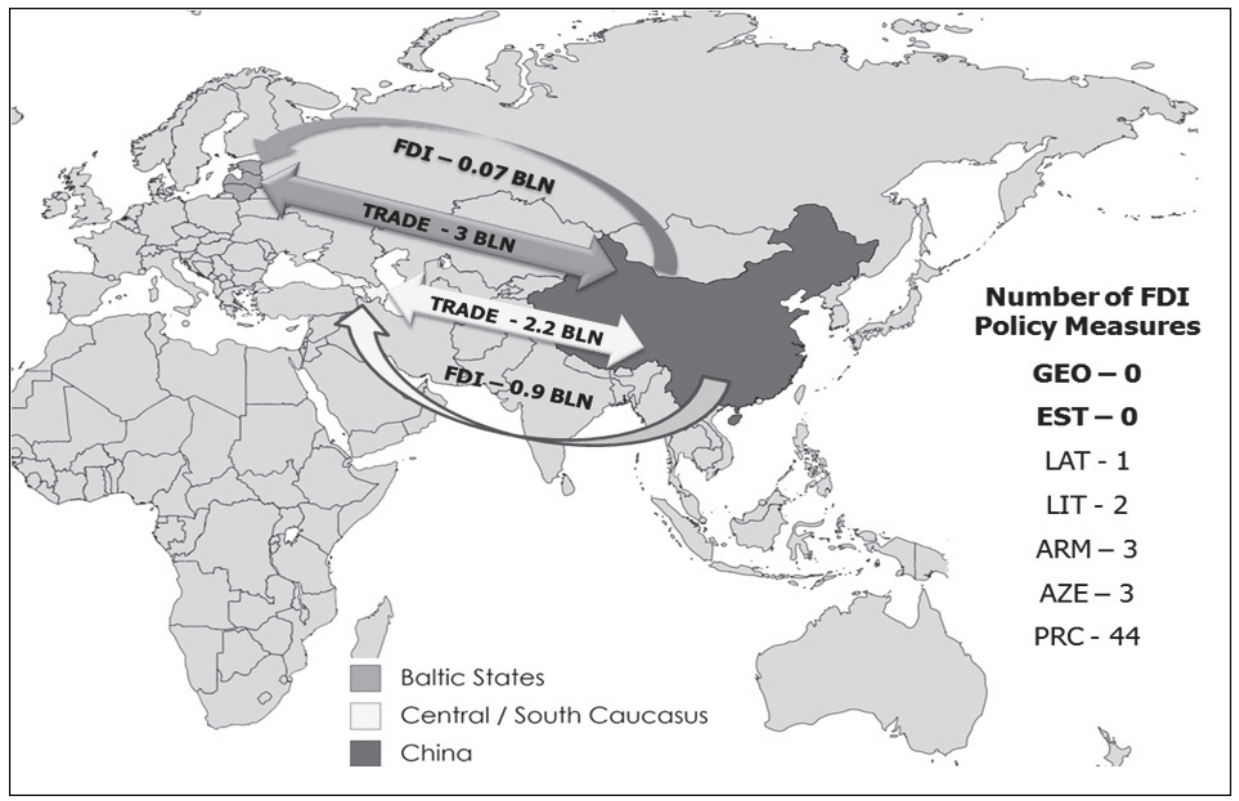

It is important to underline that all three Baltic States have a strong infrastructure, labor force and transit potential, and the problem of small market is balanced with the membership of the EU with more than 500 million consumers. FDIs are welcomed without extra barriers and pro-business legislative framework, making a solid ground for local economic development. For instance, in Estonia, which has strong IT, bio technologies and green industries, etc., companies with foreign shareholding of more than $10 \%$ provide $60 \%$ of total export, $36 \%$ of employment, $45 \%$ of value added to the economy and $28 \%$ of higher productivity (based on value added) (Ministry of Economic Affairs and Communications, 2014). Unlike the 1990s, Latvian economic development model is no longer oriented on privatization as a source of FDI but from re-investments and classic merger/acquisition operations, with strong sides in telecommunications, oil pipelines, real estate, retailing and banking sectors. In addition to the strong manufacturing, financial and insurance sectors, wholesale and retail, the sectors of technology and video games, Lithuania, as well as other Baltic States, offer tax exemptions to foreign companies. 
China, being the most restrictive country towards FDI not only compared to the European countries (Fig. 5), but worldwide, together with India and the United Arab Emirates (UNCTAD, 2018), does not make a serious problems for the Baltic and South Caucasus states, since their interest in China is limited with the FDI inflow (Chinese FDI stock equals only to 0.07 billion to the Baltics and 0.9 billion to the South Caucasus) and not with the potential of FDI outflow, increasing trade (between China and the Baltics - 3 billion, and between China and the Caucasus - 2.2 billion) and balancing cooperation with Russia.

However, increasing trade means not only increasing the amount, but also decreasing the deficit, preferably through increasing export to China. The negative trade balance between the Baltics States and China equals almost to 2.1 billion US dollars, with half of it coming from Estonia alone (Table 1). In this respect, Georgia, Armenia and Azerbaijan look more self-reliant with their higher export and less import to China, compared to the Baltic countries, but with quick increase trend in import especially in Georgia, who is becoming the third largest trade partner in a matter of only a few years.

Table 1. Trade between the Baltic and the South Caucasus countries and China, 2016

\begin{tabular}{|c|c|c|c|}
\hline COUNTRY & $\begin{array}{c}\text { EXPORT } \\
\text { (million USD) }\end{array}$ & $\begin{array}{c}\text { IMPORT } \\
\text { (million USD) }\end{array}$ & $\begin{array}{c}\text { DEFICIT } \\
\text { (million USD })\end{array}$ \\
\hline EST & 189 & 1,300 & $-1,111$ \\
\hline LAT & 132 & 444 & -312 \\
\hline LIT & 136 & 784 & -648 \\
\hline Total & $\mathbf{4 5 7}$ & $\mathbf{2 , 5 2 8}$ & $\mathbf{- 2 , 0 7 1}$ \\
\hline & & & -377 \\
\hline GEO & 170 & 547 & -264 \\
\hline ARM & 99 & 363 & -469 \\
\hline AZE & 272 & 741 & $-1,110$ \\
\hline Total & $\mathbf{5 4 1}$ & $\mathbf{1 , 6 5 1}$ & \\
\hline
\end{tabular}

Source: UN, 2016

Despite the fact that the Caucasus countries have closer FDI cooperation with China, and despite the fact that their annual FDI amount attracted worldwide is 8 times higher than in the Baltic countries (Table 2), the FDI stock for the year 2016 was almost equal in these given regions, with Azerbaijan undoubtedly in the lead both in annual and stock amounts, as well as in terms of FDI Inward as a percent of Gross Fixed Capital Formation (measures the value of additions to 
fixed assets purchased by business, government and households less disposals of fixed assets sold off or scrapped).

Table 2. FDI statistics for the Baltic and the South Caucasus States, 2016

\begin{tabular}{|c|c|c|c|c|c|c|c|c|}
\hline & EST & LAT & LIT & GEO & ARM & AZE & $\begin{array}{c}\text { Baltic } \\
\text { total }\end{array}$ & $\begin{array}{c}\text { Cauca- } \\
\text { sus total }\end{array}$ \\
\hline $\begin{array}{c}\text { Inward FDI } \\
\text { (million USD) }\end{array}$ & 870 & 126 & -208 & 1,661 & 338 & 4500 & 788 & 6,499 \\
\hline $\begin{array}{c}\text { FDI stock } \\
\text { (million USD) }\end{array}$ & 19,193 & 14,253 & 13,773 & 14,109 & 4,633 & 26,683 & 47,219 & 45,425 \\
\hline $\begin{array}{c}\text { GDP } \\
\text { (current } \\
\text { billion USD) }\end{array}$ & 23,338 & 27,573 & 42,739 & 14,378 & 10,572 & 37,848 & 93,650 & 62,798 \\
\hline $\begin{array}{c}\text { Number of } \\
\text { greenfield inv }\end{array}$ & 18 & 13 & 53 & 11 & 7 & 25 & 84 & 43 \\
\hline $\begin{array}{c}\text { FDI inwards (\% } \\
\text { of GFCF }\end{array}$ & 17.1 & 2.5 & -2.6 & 41.4 & 15.2 & 47.8 & ava 5.7 & ava 35 \\
\hline $\begin{array}{c}\text { FDI stock (\% of } \\
\text { GDP) }\end{array}$ & 83 & 51.5 & 32.2 & 99.2 & 44.1 & 71 & ava 56 & ava 71 \\
\hline
\end{tabular}

Source: Calculated by the author, based on Santander data

FDI stock makes up at least one third of GDP in the chosen countries and concludes at $99.2 \%$ in Georgia. It is clear that all the countries are significantly dependent on FDI inflow and their amount (Anguridze et al., 2015). Therefore, initiatives like the OBOR and others should be welcomed with special opportunities in these countries. As seen from Table 3, both regions are highly competitive on the global scale, laying less burden and bureaucracy on investors, offering minimum time for administrative formalities (e.g., only 84 hours in Estonia), limiting the number of payments of taxes (e.g., only 5 in Georgia), lowering share of taxes especially in the South Caucasus countries (e.g., only $16.4 \%$ in Georgia) and having stable economic growth (only Azerbaijan had some temporary substantial problems related to the dropping oil prices).

The South Caucasus, as well as the Baltic region, has great potential for attracting FDI under the OBOR initiative. Georgia has seen a stable political and economic development over the last years (Chochia \& Popjanevski, 2016); the country is one of the freest economies in the world, occupying the 9th place in doing business according to the World Bank ranking 2017, it also offers tax and legislative benefits together with one of the friendliest and attractive investment 
climates in the world (Charaia, 2014a; 2014b) and long financial stability (Papava $\&$ Charaia, 2017b; 2017c). Companies with foreign shareholding of more than $10 \%$ provide more than $2 / 3$ of the total Georgian export, foreign investments are mainly targeting the transport and telecommunications, financial sector, and construction and energy industries (Charaia, 2017a; 2018; Wang, 2018).

Table 3. Business Indicators in the Baltics and the Caucasus

\begin{tabular}{|c|c|c|c|c|c|c|c|c|}
\hline & EST & LAT & LIT & GEO & ARM & AZE & $\begin{array}{c}\text { Baltic } \\
\text { AVA }\end{array}$ & $\begin{array}{c}\text { Caucasus } \\
\text { AVA }\end{array}$ \\
\hline $\begin{array}{c}\text { Number of payments of } \\
\text { taxes per year }\end{array}$ & 8 & 7 & 11 & 5 & 14 & 6 & 8.7 & 8.3 \\
\hline $\begin{array}{c}\text { Time taken for } \\
\text { administrative } \\
\text { formalities (hours) }\end{array}$ & 84 & 168.5 & 171 & 270 & 313 & 195 & 141 & 259 \\
\hline $\begin{array}{c}\text { Total share of taxes (\% } \\
\text { of profit) }\end{array}$ & 48.7 & 35.9 & 42.7 & 16.4 & 18.5 & 39.8 & 42 & 25 \\
\hline GDP growth rate $^{*}$ & 2 & 2.1 & 2.3 & 2.8 & 0.2 & -3.1 & 2.1 & -0.3 \\
\hline
\end{tabular}

Source: Business Environment, Santander, n.d.

* GDP growth annual percent, World Bank Data

Armenia has made great progress since 1991, recognized by the World Bank and named number one country in the Commonwealth of Independent States (CIS), in terms of FDI appeal. Despite its huge economic and political dependence on Russia, Armenia never stopped its progress and cooperation with the EU, and has benefited with a significant amount of FDIs from the EU countries in energy, telecommunications and metallurgy. It is important to underline that significant investments are also made by the Armenian diaspora accounting for two times more people than the population of the country.

Azerbaijan's economy and FDI attraction has been rising progressively in the last years and is mainly oriented to the energy sector (oil and gas sector). According to recent changes in Customs Tariff Law, importing equipment for priority sectors will be exempted of taxes for up to seven years. Construction permits, getting electricity and securing credits are the most problematic fields for Azerbaijan, but it has not proved to be a problem in attracting the highest number of annual FDIs in the region. 
Being widely reluctant and unwilling to be involved in the conflict resolution process in the South Caucasus region (Shahbazov, 2017), the country could still play a role of a balancer of Russian interests in the region. The cost of conflict is not only high but it prevents future economic progress, therefore it should be a matter of special care for the Caucasus countries (Charaia, 2016).

\section{Conclusion}

The world is changing and globalization is already selective. China's global aspirations are growing but so far limited. After long transformation and considerable economic growth, China tries to enhance its outflow of Foreign Direct Investments through the One Belt, One Road initiative to obtain strategic benefits, however not everywhere those investments are welcomed, especially in western EU Member States.

Despite the fact that some European countries like Belgium, the Netherlands, Denmark, the Slovak Republic and Hungary have a negative trade balance with China, they are highly dependent on this trade. Therefore, limiting import from China, which could create a mirror effect from the opposite side, could harm European countries as well. The same goes for investments, however the attitude of the western and eastern EU Member States are different-while the western countries are trying to impose some extra barriers to (Chinese) FDI, the eastern states are largely welcoming those financial inflows.

So far neither the Baltic States nor the South Caucasus countries are directly linked to the OBOR project or even officially mentioned on the main transit corridors from China to the rest of the world. The authors believe that there could be alternatives and the European gate should start in South Caucasus. The potential of the Baltic States and South Caucasus is underestimated.

Currently the land route from China to Europe proposed by Beijing goes around Caucasus, through Iran and Turkey. These routes are unstable for transportation, especially considering the permanent sanctions on Iran and the political problems between EU/USA and Turkey. Moreover, there already exists great potential and infrastructure through Azerbaijan and Georgia, and further on to the Baltic States. Both trade and investments could be promoted through this corridor and it is important to underline that this direction is the shortest way to transport goods from China to Europe. Cargo sent from Lianyungang, China's easternmost port city, would take a maximum of 14-15 days to reach 
Istanbul, which is quite incredible, given that the same journey by sea would take approximately 45 days.

Even choosing the Iran route, there is a possibility of connecting Tehran with Yerevan and further with Anaklia Port in Georgia; however this route unlike the first one (Aktau-Baku-Anaklia), has to attract a considerable amount of investment, therefore is less likely to succeed.

Free Trade Agreements, which Georgia simultaneously has with the EU and China, makes the $\mathrm{C} 3$ plus B3 project even more realistic. South Caucasus and Georgia in particular could be used not only as a transit corridor but also to attract Chinese and EU investments later on to export it to European and/or Chinese markets with the free trade regime and minimum amount of barriers, which is a great problem nowadays, especially when speaking about China-EU trade and investments.

Dr. Vakhtang Charaia is an associated professor at Grigol Robakidze University and head of the TSU Center for Analysis and Forecasting. At different times he has studied and carried out his PhD researches at Tbilisi State University (Georgia), Passau University, University of Bremen (Germany), European University in St. Petersburg (Russia), Institute of Government Accounts and Finance (India), University of Tartu (Estonia) and George Washington University (USA). Prof. Charaia has published more than 30 scientific articles in peer-reviewed academic journals, several books and chapters in different books. He is the Best Young Scientist (Economist) of Georgia for the year 2018. His research fields are free trade regimes, foreign direct investment, international trade, peace-building and conflict resolution.

Dr. Archil Chochia is a researcher at Tallinn Law School of Tallinn University of Technology, Tallinn. Dr. Chochia obtained his doctoral degree from the Tallinn University of Technology (now Taltech) in 2013, while he has previously studied at the University of Scranton, Tbilisi State Medical University, University of California, Pepperdine University and Harvard University. He has more than 70 academic publications as articles in peer-reviewed academic journals, chapters in books, doctoral dissertation and conference papers. He is a co-editor of the books Political and Legal Perspectives of the EU Eastern Partnership Policy (Springer, 2016) and Brexit: History, Reasoning and Perspectives (Springer, 2018). His research fields of interest are law and technology, alternative dispute resolution, EU integration, EU Neighbourhood policy. Archil Chochia is a Senior Fellow of the Weinstein International Foundation.

Mariam Lashkhi is a junior researcher and project coordinator at the TSU Center for Analysis and Forecasting. She has graduated from the Tbilisi State University and is 
actively involved in (economic) research projects often published at different analytical platforms. Mariam has participated in various local and international conferences and published several articles in peer-reviewed academic journals. Her research interests are China-Georgia-EU economic cooperation, international economic relations, economics of developing countries and Foreign Direct Investments.

\section{References}

Anguridze, O.; Charaia, V. \& Doghonadze, I. (2015), Security Problems \& Modern Challenges of the Georgian National Currency, Tbilisi: Ivane Javakhisvhili Tbilisi State University \& TSU Centre for Analysis and Forecast. Retrieved from http:// press.tsu.ge/data/file_db/nashromebi/Security-Problems-Modern-Challenges-ofthe-Georgian-National-Currency2\%20(1).pdf [accessed Nov 2018]

Barone, B. (2015), One Year To Go: The Debate over China's Market Economy Status (MES) Heats up, Brussels: European Parliament Policy Department, DirectorateGeneral for External Policies. Retrieved from https://www.eesc.europa.eu/ resources/docs/one-year-to-go.pdf [accessed Nov 2018]

Bērziņa-Čerenkova, U.A. (2018), 'China's new role in the Baltic States,' FIPRI, Baltic Bulletin, 30 January. Retrieved from https://www.fpri.org/article/2018/01/chinasnew-role-baltic-states/ [accessed Nov 2018]

Bochra, M. (2015), 'One Belt, One Road,' The New Silk Road and the Baltic Sea Region, Baltic Transport Journal, no. 4, pp. 60-62. Retrieved from http://www. baltic-press.com/hr007_hr360_summary/05_btj66_60-62.pdf [accessed Nov 2018]

Charaia, V. (2014a), 'Role of FDI for Countries Economic Development. The Case of Georgia.' Paper presented at the 9th IBSU International Silk Road Conference on Business, Economics, International Relations and Education, 23-25 May, 2014, Tblisi, Georgia. Abstract retrieved from https://silkroad.ibsu.edu.ge/silkroad/ index.php/silkroad/silkroad9th/paper/viewPaper/292 [accessed Nov 2018]

Charaia, V. (2014b), 'Local investment climate and the role of (sustainable) FDI: The case of Georgia,' International Journal of Social, Behavioral, Educational, Economic, Business and Industrial Engineering, vol. 8, no. 2, pp. 549-552. Retrieved from http://waset.org/publications/9997562/local-investment-climateand-the-role-of-sustainable-fdi-the-case-of-georgia [accessed Nov 2018]

Charaia, V. (2016), 'Economics of conflict: Core economic dimensions of the GeorgianSouth Ossetian context,' International Journal of Humanities and Social Sciences, vol. 3 , no. 10 .

Charaia, V. (2017a), 'The role of multinational enterprises' investments in emerging country's economic development: Case of Georgia,' World Academy of Science, 
Engineering and Technology, International Journal of Social, Behavioral, Educational, Economic, Business and Industrial Engineering, vol. 11, no. 3, pp. 721-724. Retrieved from http://www.waset.org/publications/10006953 [accessed Nov 2018]

Charaia, V. (2017b), Trade and Investment Relations between Georgia and China, Expert Opinion no. 94, Tbilisi: Georgian Foundation for Strategic and International Studies. Retrieved from https://www.gfsis.org/files/library/opinion-papers/94expert-opinion-eng.pdf [accessed Nov 2018]

Charaia, V. (2018), 'FDI Motivation and Benefits for Georgia,' Ekonomisti, no. 1. Retrieved from http://ekonomisti.tsu.ge/?cat=nomer\&leng=eng\&adgi=253\&title $=$ FDI\%20MOTIVATION\%20AND\%20BENEFITS\%20FOR\%20GEORGIA[1] [accessed Nov 2018]

Chochia, A. \& Popjanevski, J. (2016), 'Change of power and its influence on country's Europeanization process. Case study: Georgia,' in T. Kerikmäe \& A. Chochia (eds.) Political and Legal Perspectives of the EU Eastern Partnership Policy, Cham: Springer International Publishing, pp. 197-210. https://doi.org/10.1007/978-3-319-27383-9_13

Dobrin, S. \& Chochia, A. (2016), 'The concepts of trademark exhaustion and parallel imports: A comparative analysis between the EU and the USA,' Baltic Journal of European Studies, vol. 6, no. 2, pp. 28-57. https://doi.org/10.1515/bjes-2016-0011

Éltető, A. \& Antalóczy, K. (2017), 'Export promotion aims and reality: A comparison of the Iberian, Baltic and Central European region,' Baltic Journal of European Studies, vol. 7, no. 1, pp. 43-63. https://doi.org/10.1515/bjes-2017-0004

Eurostat (2018), China-EU: International trade in goods statistics. Retrieved from http:// ec.europa.eu/eurostat/statistics-explained/index.php/China-EU_-_international_ trade_in_goods_statistics [accessed Nov 2018]

Ferraro, S.; Dutt, K. P. \& Kerikmäe, T. (2017), 'Using patent development, education policy and research and development expenditure policy to increase technological competitiveness of small European Union Member States,' Croatian International Relations Review, vol. 23, no. 78, pp. 97-126.

https://doi.org/10.1515/cirr-2017-0009

Hanemann, T. \& Huotari, M. (2017), Record Flows and Growing Imbalances: Chinese Investment in Europe in 2016, MERICS Papers on China, no. 3. Retrieved from https://www.merics.org/sites/default/files/2017-09/MPOC_3_COFDI_2017.pdf [accessed Nov 2018]

Hansakul, S. \& Levinger, H. (2014), China-EU Relations: Gearing up for Growth, Deutsche Bank Research, Frankfurt-am-Main: Deutsche Bank. Retrieved from https:/www.dbresearch.de/PROD/RPS_DE-PROD/PROD0000000000451972/ China-EU_relations\%3A_Gearing_up_for_growth.pdf [accessed Nov 2018]

Hellström, J. (2016), China's Acquisitions in Europe: European Perceptions of Chinese Investments and the Strategic Implications, Report no. FOI-R-4384- 
SE. Retrieved from https://www.foi.se/download/18.6f5585fa15a36ec7a961b 9b/1487592009526/foir_4384.pdf [accessed Nov 2018]

Kaplan, Y. (2017), 'China's OBOR as a geo-functional institutionalist project,' Baltic Journal of European Studies, vol. 7, no. 1, pp. 7-23. https://doi.org/10.1515/bjes-2017-0002

Kerikmäe, T. \& Zuokui, L. (2017), 'New perspectives for Europe-China relations,' Baltic Journal of European Studies, vol. 7, no. 1, pp. 3-5. https://doi.org/10.1515/bjes-2017-0001

Larçon, J. P. (2017), The Economic Impact of China on the Baltic Sea Region, BSR Policy Briefing series, Centrum Balticum. Retrieved from http://www.centrumbalticum. org/files/3259/BSR_Policy_Briefing_5_2017.pdf [accessed Nov 2018]

Lashkhi, M. \& Charaia, V. (2017), 'Investment development path and motivations for Foreign Direct Investment in Georgia,' World Academy of Science, Engineering and Technology, International Journal of Economics and Management Engineering, vol. 11 , no. 11, p. 3213

MERICS (2015), The Great Fallout: Why China's Slowing Trade is Sending Shockwaves through the World, Mercator Institute for Chinese Studies, 11 November. Retrieved from https://www.merics.org/en/china-mapping/great-fallout-why-chinasslowing-trade-sending-shockwaves-through-world [accessed Nov 2018]

Ministry of Economic Affairs and Communications (2014), Made in Estonia 3.0.: The Estonian foreign investments and export action plan for the years 2014-2017 for increasing the export capacity of Estonian companies and involving foreign investments, p. 8. Retrieved from https://www.mkm.ee/sites/default/files/mie_3.0_ english_version.pdf [accessed Nov 2018]

Muenchow-Pohl, B. von (2012), 'EU Relations with China and India: Courting the dragon, wooing the elephant,' Carnegie Endowment for International Peace, 23 August. Retrieved from http://carnegieendowment.org/2012/08/23/eu-relationswith-china-and-india-courtingdragon-wooing-elephant-pub-49173 [accessed 19 Jul 2017]

Okano-Heijmans, M. \& van der Putten, F.-P. (2009), 'Europe needs to screen Chinese investment,' Financial Times, 12 August. Retrieved from https://www.ft.com/ content/8ba0192e-86b7-11de-9e8e-00144feabdc0 [accessed 13 Aug 2017]

Papava, V. \& Charaia, V. (2014), 'Regional railways in the Central Caucasus and Georgia's economic interests,' The Caucasus \& Globalization, vol. 8, nos. 1-2.

Papava, V. \& Charaia, V. (2017a), 'Belt and Road Initiative: Implications for Georgia and China-Georgia economic relations,' China International Studies, no. 67, pp. 122-139. Retrieved from http://eprints.tsu.ge/369/1/Charaia-Papava_Beltand-Road_Georgia.pdf [accessed Nov 2018] 
Papava, V. \& Charaia, V. (2017b), 'The role of inflation and its targeting for lowincome countries (Lessons from post-Communist Georgia),' European Journal of Economic Studies, vol. 6, no. 2, pp. 96-103. Retrieved from http://ejournal2.com/ journals_n/1504096069.pdf [accessed Nov 2018]

Papava, V. \& Charaia, V. (2017c), Inflation Index Modifications and Expediency of Their Application for Georgia, Expert Opinion no. 77, Tbilisi: Georgian Foundation for Strategic and International Studies. Retrieved from http://www.gfsis.org/files/ library/opinion-papers/77-expert-opinion-eng.pdf [accessed Nov 2018]

Rasmussen Global (2017), Foreign Investment Screening and the China Factor: New Protectionism or New European Standards? Rasmussen Global Report. Retrieved from https://rasmussenglobal.com/media/foreign-investment-screening-chinafactor-memo [accessed Nov 2018]

Santander (n.d.), Santander Trade Portal. Retrieved from https://en.portal.santandertrade. com/ [accessed Nov 2018]

Shahbazov, F. (2017), 'Baku-Beijing Relations and China's growing interest in the South Caucasus,' Eurasia Daily Monitor, vol. 14, no. 51. Retrieved from https:// jamestown.org/program/baku-beijing-relations-chinas-growing-interest-southcaucasus/ [accessed Nov 2018]

Shelia, R. (2015), 'First train from China arrives in Georgia-New Silk Road now officially open,' Georgian Journal, 17 December. Retrieved from https://www. georgianjournal.ge/politics/31972-first-train-from-china-arrives-in-georgia-newsilk-road-now-officially-open.html [accessed Nov 2018]

Šteinbuka, I.; Muravska, T. \& Kuznieks, A. (2017), 'Cooperation formats of China and Europe: Synergies and divergences,' Baltic Journal of European Studies, vol. 7, no. 1, pp. 98-118. https://doi.org/10.1515/bjes-2017-0007

Sunesen, E. \& Hansen, M. (2018), Screening of FDI towards the EU, Copenhagen: Copenhagen Economics. Retrieved from https://www.copenhageneconomics. com/dyn/resources/Publication/publicationPDF/2/422/1516371455/copenhageneconomics-2018-screening-of-fdi-towards-the-eu.pdf [accessed Nov 2018]

UN (2016), 'UN Database.' Retrieved from https://comtrade.un.org/data/ [accessed Nov 2018]

UNCTAD (2017), 'Statistics,' United Nations Conference on Trade and Development, p. 103. Retrieved from http://unctad.org/en/Pages/Statistics.aspx [accessed Nov 2018]

UNCTAD (2018), 'Investment Policy Monitor,' United Nations Conference on Trade and Development. Retrieved from http://investmentpolicyhub.unctad.org/IPM [accessed Nov 2018]

Wang, F.; Papava, V. \& Charaia, V. (2018), 'China-Georgia Economic Relations in the Context of the Belt and Road Initiative. Bulletin of the Georgian National Academy of Sciences, vol. 12, no. 1, pp. 154-157. Retrieved from https://slidego. 
org/Engineering/china-georgia-economic-relations-in-the-context-of-the-beltand-road-initiative [accessed Nov 2018]

Yalcin, E.; Felbermayr, G. \& Sandkamp, A. (2016), New Trade Rules for China? Opportunities and Threats for the EU, Munich: Ifo Institute \& European Parliament DG External Policies, Policy Department.

Yin, W. \& Zhang, A. (2017), 'A new proposed EU framework for screening foreign direct investment,' Leiden Law Blog, 10 October. Retrieved from http://leidenlawblog.nl/ articles/a-new-proposed-eu-framework-for-screening-foreign-direct-investment [accessed Nov 2018]

Zhang, L.; Grešš, M. \& Brocková, K. (2017), 'Current and potential Chinese Foreign Direct Investment in the Slovak Republic,' Baltic Journal of European Studies, vol. 7, no. 1, pp. 85-97. https://doi.org/10.1515/bjes-2017-0006 